Article

\title{
Integration, Application and Importance of Collaboration in Sustainable Project Management
}

\author{
Johan Larsson $1, *(1)$ and Lisa Larsson ${ }^{2}(\mathbb{D}$ \\ 1 Department of Civil, Environmental and Natural Resources Engineering, Luleå University of Technology, \\ 97187 Luleå, Sweden \\ 2 Department of Business Administration, Technology and Social Sciences, Luleå University of Technology, \\ 97187 Luleå, Sweden; lisa.larsson@ltu.se \\ * Correspondence: johan.p.larsson@1tu.se
}

Received: 29 November 2019; Accepted: 9 January 2020; Published: 13 January 2020

\begin{abstract}
The need to consider sustainability has substantially increased the complexity of implementing construction and infrastructure projects and new management practices have emerged during the past decade to tackle the global sustainability challenges, where the engagement and coordination of broader competences from stakeholders throughout the supply chain is required. This new project management paradigm has been accompanied by greater attention to the concept of collaborative business arrangements, often called partnering, that has emerged in construction and infrastructure projects to improve project deliveries. However, there are uncertainties about the optimal strategy to foster, integrate and maintain the required collaboration, particularly in sustainable management practices in infrastructure maintenance projects. This paper addresses these uncertainties, based on a single case study of an infrastructure maintenance contract involving an extensive collaborative business arrangement. The findings reveal that different collaborative practices affect diverse aspects of sustainable project management. Further, the extensive collaborative business arrangement has promoted sustainable deliveries based upon organizational learning and continuous improvements. Thus, this study offers an encouraging example of how extensive collaboration can be fostered and play a key role in sustainable project management practices.
\end{abstract}

Keywords: sustainability; project management; collaboration; business arrangement; maintenance; infrastructure

\section{Introduction}

Engagement of multiple specialties and competences, which are seldom present in a single organization, is required for the implementation of construction and infrastructure projects. Moreover, the increasing importance of considering sustainability has further increased the organizational complexity of implementing projects, and hence the management of projects [1]. These projects require coordination of numerous stakeholders with varying organizational practices and project expectations [2,3]. Nevertheless, the most common management approach involves competitive procurement practices and subsequent control and surveillance during implementation $[4,5]$. This traditional project management approach is mainly applied in attempts to ensure that projects are delivered within set scope, time, budget and quality constraints [6]. This has undeniable importance for process performance, if handled appropriately [7], but the approach has been criticized due to deficiencies for handling the growing complexity of implementing projects [6]. Consequently, new management practices have emerged during the past decade to tackle increasing challenges, such as the global sustainability challenge [8-10]. The following definition has been suggested for the emerging sustainable project management practices [1]: "Sustainable Project Management is the planning, 
monitoring and controlling of project delivery and support processes, with consideration of the environmental, economic and social aspects of the life-cycle of the project's resources, processes, deliverables and effects, aimed at realizing benefits for stakeholders, and performed in a transparent, fair and ethical way that includes proactive stakeholder participation." This definition implies a more holistic approach to projects in which multiple stakeholders are both engaged in project management activities [11] and gain from the project delivery in social and environmental as well as monetary terms.

This new project management paradigm seems to have been accompanied by increases in attention to collaborative business arrangements, often called partnering, which have emerged in construction and infrastructure projects to improve project deliveries [12,13]. These arrangements collectively represent a paradigmatic shift from traditional competitive business arrangements since they are intended to integrate the entire supply chain and form a coherent system based on effective coordination of multiple stakeholders [12,14]. Needs for integration of various competences and collaboration of various stakeholders have become increasingly apparent for successful management of the complex and uncertain endeavors involved in inter-organizational infrastructure projects [15]. However, while there is substantial literature on effects of collaborative business arrangements on traditional project performance parameters (time, cost, quality) and innovation $[4,16]$, their benefits for sustainability and sustainable project management have received much less attention. Moreover, previous construction and infrastructure management studies have mostly focused on investment projects, e.g., $[13,17]$, while the long and expensive maintenance phase has largely been neglected. This phase is at least as complex as the investment phase, since it often involves activities in busy roads or other infrastructure, which disrupts the everyday lives of many people and stakeholders throughout the products' extensive life cycles [18]. Thus, collaboration between multiple stakeholders is highly important to minimize the disruptions and reduce both the required maintenance work and consumption of resources.

The global trend of increased attention to collaborative business arrangements is pronounced in public infrastructure projects $[17,19]$. These projects often involve long business arrangements, bounded by a contract between a public client and suppliers, with the objective to maintain or increase the quality of the initial investments throughout their extensive life spans. For example, in Sweden, the major public client of infrastructure, the Swedish Transport Administration (STA), has strongly promoted increases in collaboration to drive substantial performance improvements during the implementation of business projects. However, there are uncertainties about the optimal practices for fostering and maintaining such collaboration. The aim of this paper is to increase the understanding of how to integrate and apply collaboration as part of sustainable management in infrastructure maintenance projects. The findings are based on a single case study of an infrastructure maintenance contract between a Swedish municipality and a major supplier. The studied contract involves an uncommon project setting based on a rather long business arrangement (7 years) with extensive collaboration built on trust, open communication and common goals.

The rest of the paper is structured as follows. Section 2 introduce previous literature on sustainability and sustainable project management, and the role of collaboration in construction projects. Section 3 then describes the methodology including research design, a brief case description, data collection and applied analytical techniques. In Section 4, the empirical findings from the collaborative business arrangement are presented. The empirical findings are after discussed in Section 5 in relation to previous literature, emphasizing on collaboration as part of sustainable project management. In Section 6, conclusions are drawn, and theoretical and managerial implications are offered.

\section{Literature Review}

\subsection{Sustainability and Sustainable Project Management}

Probably the most commonly used definition of sustainable development is "development that meets the needs of the present without compromising the ability of future generations to meet their own needs" [20]. 
Sustainability is often conceptualized in terms of three dimensions or 'pillars' - environmental, economic and social—often referred to as the triple bottom line or Triple-P (People, Planet, Profit). In order to truly contribute to sustainable development, all three pillars must be considered simultaneously [21], as they are interrelated and progress in one dimension must not compromise progress in another dimension. However, publications on sustainable development often focus on one dimension, most frequently the economic dimension and its relation to the environmental dimension [1].

Ultimately, projects play a significant role in the realization of more sustainable business practices [1]. However, sustainable development including environmental, economic and social aspects is rarely considered, or at least prioritized in temporary organizations such as those formed to implement projects [22]. Five dimensions of sustainable project management have been highlighted in a recent review of literature on the integration of sustainability into project management: corporate policies and practices, resource management, life cycle orientation, stakeholder engagement, and organizational learning [8]. To some extent these dimensions also cover dimensions mentioned in other publications on the topic, e.g., value, time, geographic, and performance dimensions [1]. The key practical challenge, addressed here, is to identify effective means to improve project management in terms of these dimensions, which are briefly described below.

Corporate policies and practices-The rules, processes and decisions used to translate strategy into projects define the context for management practices at individual project level [23], and hence influence relevant practices of all the stakeholders involved in a project. Thus, to effectively incorporate sustainability principles into project management, organizations should first consider sustainability on a corporate level, outlining policies and project management practices that define how to do business [8]. Moreover, it has been argued that corporate sustainability and the implementation of specific projects are strongly linked [8], implying that the most relevant sustainability aspects of any project should be consistently and transparently assessed [24].

Resource management-Most definitions of sustainability refer to the responsible use of resources, e.g., $[1,20]$. Sustainable project management has even been regarded as minimization of the resources used in a project, from initiation to completion [25]. From a wider life cycle perspective, sustainability should embrace resource management in the decommissioning stage of the project's deliverable (in terms of durability, reusability and recyclability) [26]. This is especially relevant in construction projects, which generally consume substantial amounts of resources, and hence may potentially have substantial negative environmental effects [27]. Moreover, sustainable project management implies management of not only economic capital, but also social and environmental capital [1]. Thus, project managers should, inter alia, consider the social capital of the organization, permanent or temporary, and not compromise the employees' ability to produce [28].

Life cycle orientation-Integrating the concept of sustainability into project management may stretch the 'system boundaries' of project management in a life cycle perspective [29]. Incorporating sustainability in the project requirements and assessment of project success and business cases implies consideration of economic, social and ecological aspects in both the short and long term. This, in turn, requires adoption of a life cycle perspective in the planning and implementation of the project and consideration of its outcomes [30,31], in terms of both quantitative and qualitative criteria [32]. The procurement and selection of suppliers also provide logical opportunities to consider sustainability [33] from the outset of a project.

Stakeholder engagement - In a sustainable project management process it is essential to consider and respect potential interests of stakeholders. Hence, there are needs for a joint, open, flexible, and detailed negotiation and shaping process involving multiple stakeholders [34] and a detailed communication plan to ensure that stakeholders are informed throughout the project [35]. Three main groups of stakeholders that should be considered in such a process have been identified: individual (the project manager and project team members), organizational (project sponsors and shareholders), and global 
society (local and global communities) [34]. It is important to recognize that needs of all stakeholders, not just shareholders or financiers should be considered [36].

Organizational learning-The degree to which organizations involved in a project learn from it also influences sustainability. Projects provide good opportunities for continuous learning, due to the inclusion of specific knowledge management processes, which facilitate accumulation of knowledge generated by experience [37]. Since project team level-learning also occurs, organizations should provide teams with training about sustainability to incorporate its consideration during all project phases [8]. Further, incorporating sustainability as an underlying objective in projects may enhance teams' commitment, engagement and performance [38].

In conclusion, sustainable project management demands shifts in scope, paradigm and mindset [38]. The scope shift entails a transition from the traditional project management approach of managing time, cost and quality to managing social, environmental and economic impacts [39]. The paradigm shift involves transition from prioritization of controllability and predictability, which have little relevance in a long-term and global perspective, as relevant changes are difficult to foresee. The required shift in mindset includes recognition that project management must include not only management of stakeholders in the traditional sense, but also engagement with them in joint realization of the sustainable development of an organization or society. Adding new perspectives to projects and project management also adds complexity [39], which means that a more holistic and less mechanical approach is needed in any new business strategy $[22,40]$.

\subsection{Collaboration in Construction Projects}

Organizations in the construction industry are structured to deliver unique and complex products and systems in specific inter-organizational projects [41]. The projects are ordered by a specific external client (or group of clients) and involve extensive design and production of one-off solutions. A delivery usually consists of customized products or systems integrated in a business-to-business arrangement bounded by a contract between a client and a (main) supplier [42]. Due to the complexity of each delivery, the main supplier seldom has all the knowledge needed to deliver the solution, and so a number of competences and stakeholders need to be coordinated throughout the supply-chain to enable efficient delivery and adequate outcome [3,41]. However, previous studies have revealed that complex construction and infrastructure projects are often plagued by cost and time overruns [43,44]. Hence, numerous studies have investigated causes of these overruns and found evidence that traditional project management approaches are inappropriate in these inter-organizational and complex endeavors [15]. The traditional approach involves control-focused practices based on competitive procurement procedures and extensive planning, with subsequent control and surveillance during implementation [5].

In efforts to improve the industry, scholars and practitioners have recently turned their attention towards collaborative business arrangements [12,13], not least to facilitate realization of sustainable development [45]. Collaborative 'partnering' arrangements have shown potential to improve business in other contexts $[19,46]$. There is no universal understanding of the concept [47], but much of the relevant literature refers to definitions that incorporate long-term commitment from multiple stakeholders in efforts to achieve common business objectives. This requires effective coordination of multiple project resources and stakeholders in the supply chain. Further, relationships within the supply chain should be based on trust [48], commitment to common goals, and mutual understanding of each actor's expectations and values. Often mentioned benefits include increases in efficiency, cost-effectiveness, opportunities for innovation and improvements in project deliveries [12]. However, several scholars have stressed that collaboration per se does not guarantee project success $[4,12]$. Suggested reasons for this include the complexity of establishing and maintaining trust and cooperative relationships during long-lasting inter-organizational projects [14]. There is also an ongoing debate on whether collaborative relationships can be "engineered" in single projects, or if success needs a change in culture that evolves over a longer period of time [49]. The engineered path focus on formal 
and systematic integrative tools and techniques, such as procurement procedures and teambuilding activities, whereas the evolutionary path instead focuses on social and informal aspects of relationships. To further our understanding of collaboration in construction projects, a theoretical framework has been developed by Eriksson [14] based on general supply-chain integration literature, e.g., [50,51]. The proposed framework includes four dimensions of collaboration-duration, intensity, depth and width [14] — which are interrelated and affected by both early procurement procedures and management practices during project implementation.

Duration refers here to the length of the time during which stakeholders will collaborate and participate in joint development and other integrative activities [14]. Hence, the duration of collaboration is strongly related to the procurement procedure, and thus each stakeholder's entry point. Prior studies have shown that increases in this duration strengthen the integration, partly because the involved stakeholders get to know each other and build mutual trust over time, and partly because people are more eager to behave well if they expect to interact with someone repeatedly [14,52]. The intensity dimension refers to the degree or strength of integration. This dimension primarily concerns the extent to which integrative activities and tools are used [53,54]. Examples include formulation of joint goals and continuous follow-up, which strengthens stakeholders' shared orientation [55]; a joint project office, which enhance face-to-face communication [56]; and teambuilding activities involving socialization of stakeholders [57]. Prior studies indicate the importance of selecting (using multiple criteria) the right partners that are willing and competent to collaborate [58]. In addition, incentive-based payment is important since it allocates profits equitably, and signals that collaboration is valid and wanted [55]. Accordingly, prior literature emphasizes the influence of procurement and contracting procedures on the intensity and strength of collaboration [14,55]. The depth of the collaboration refers to the integration of different types of professionals and functions at multiple hierarchal levels of each participating stakeholder [14]. Many partnering arrangements in construction only involve management levels [14], but literature suggests that participation of lower levels strengthens the collaboration [52]. The last dimension is the width, which refers to the nature and number of external stakeholders engaged in the collaboration [51]. In inter-organizational construction projects this includes the number of stakeholders engaged in joint activities and development during the implementation [14]. A context-specific characteristic of construction projects is their complexity in terms of diverse interdependent contractors, suppliers, and technical consultants that require coordination [14]. Thus, this dimension is critical during the implementation of construction projects.

These collaboration dimensions are found to often be interconnected and Eriksson [14] stresses the importance of managing them simultaneously rather that in isolation. Thus, it is not enough to focus on integrative activities during project implementation to strengthen collaboration. It is also essential to engage suitable stakeholders with appropriate competences to obtain appropriate width and depth. Further, due to the complexity of construction projects, long duration is crucial, because it takes time and timing for relationships to evolve, which means that involving appropriate stakeholders and competences at appropriate times is essential [13,14,49].

However, despite construction management scholars' interest in partnering and collaborative business arrangements $[14,17,46]$, there is a lack of literature on how these practices may affect sustainability and the realization of sustainable project management. The incorporation of sustainability into business arrangements further enhance the need to stretch the 'system boundaries' of project management practices beyond the traditional short-term, by also include long-term societal effect [29]. The stretch also infers an increase in complexity and hence, the need to engage a larger number of stakeholders into the implementation $[1,8]$. Consequently, we propose that long-term collaborative arrangements may be an important feature of sustainable project management that incorporates a more holistic approach. 


\section{Methodology}

\subsection{Research Design and Case Background}

In exploratory research, case studies have documented value, as they can provide rich data and understandings regarding complex interactions and behavior, illuminate poorly understood characteristics of processes, and detect new features of focal phenomena [59]. Thus, we found it highly suitable for the analysis presented here, since management of maintenance projects is a complex endeavor that has not been thoroughly studied. It has several widely recognized limitations, inter alia, analyzing the vast amount of collected information and clearly presenting it is challenging, and conclusions cannot be readily generalized [59]. However, despite these limitations, in-depth single case study of a public sector maintenance project seemed a suitable approach to acquire relevant data and increase understanding of an important, but rather neglected, complex contemporary phenomenon.

We collected data regarding a unique public maintenance contract procured and managed by a municipality in Sweden. The primary objective of the data collection was to gather in-depth data to obtain a holistic view of the unique case. A maintenance contract was chosen partly because, as already mentioned, most construction management literature addressing transport infrastructure focuses on investment projects, e.g., $[7,9,19]$, while the long maintenance phase is largely neglected by scholars. Moreover, clients' procedures when managing maintenance projects during the long life cycle of a transport infrastructure system may strongly influence sustainability aspects. For example, these procedures may both directly affect everyday lives of many people, and the environmental impact arising from factors such as use of heavy machinery and asphalt [60,61]. Another major reason for selecting the focal case was that it involved an uncommon project setting, based on a collaborative business arrangement that has not been previously applied in Sweden. It is based on a 7 year contract between the public client and main supplier, with an explicitly stated common project goal to deliver more road maintenance for taxpayers' money. The focus on a long-term collaborative business arrangement may increase our understanding of a concept (partnering) that is paradoxically often implemented in short-term investment projects although it is based on mutual trust and long-term collaboration [12]. Access to data about the arrangements was another important case selection factor, as information about maintenance business arrangements, especially collaborative arrangements in the midst of the implementation phase, is generally difficult to access. The uncommon nature of this phenomenon provided further justification for choosing a single case study approach [59].

\subsection{Data Collection and Analysis}

The main sources of the data considered here were semi-structured interviews with key respondents from both the client and supplier organizations (hereafter the 'actors' sometimes, for convenience) intended to obtain detailed insights into a wide range of aspects of the specific business arrangement. The respondents had roles at various hierarchical levels in their respective organizations, from operational supervisors to the supplier's top regional managers and municipality departmental manager (Table 1). We also visited the project office several times, and on each occasion not only conducted interviews but also attended project meetings and engaged in informal discussions with several project members. These visits, together with secondary data in terms of presentations and documents were collected from both actors and interesting information was clarified during interviews and the informal discussions.

An interview guide was developed and used during all interviews to keep the data collection as consistent and coherent as possible. The guide covered potentially relevant background information and included several questions concerning each of the overarching themes (prerequisites, procurement procedure, working methods within the project including collaboration activities, innovation system, development work, attitudes, and deliveries). The respondents were encouraged to express opinions beyond the scope of the formal questions during the interviews, to gain richer data and capture their 
interpretations and reflections. The interviews were audio-recorded and subsequently transcribed verbatim to enable investigator triangulation [62] and ease the analysis.

Table 1. Roles of the respondents and lengths of the interviews.

\begin{tabular}{cccc}
\hline Actor & Resp. & Position/Role & Length [min] \\
\hline Supplier & 1 & Regional manager (responsible contract manager) & 86 \\
& 2 & Business manager & 71 \\
& 3 & Site manager (earthwork) & 95 \\
& 4 & Site manager (asphalt) & 72 \\
& 5 & Operational manager & 42 \\
\hline Client & 6 & Department manager & 88 \\
& 7 & Division manager (responsible contract manager) & 86 \\
& 8 & Division manager (new) & 36 \\
& 9 & Procurement manager & 53 \\
& 10 & Assistant procurer & 62 \\
& 11 & Project manager (responsible for daily operations) & 100 \\
& 12 & Project manager (design and planning) & 61 \\
& 13 & Project manager & 38 \\
\hline
\end{tabular}

The acquired data were analyzed following widely recognized steps for qualitative research: data reduction, data display, and finally drawing and verification of conclusions [63]. We first transferred the transcribed interviews into computer assisted qualitative data analysis software (NVivo 12) to organize the information. The software supports qualitative analysis by helping to manage vast amounts of data and simplifying the structuring of data, creation of codes and discovery of themes [64]. The data were first categorized into the different phases of the collaborative business arrangement (prerequisites, procurement, contract agreement, organization and operations) in order to structure the material, which later also provided the opportunity to position different occurrences in time. As a next step, we coded the data into categories based on the four dimensions of collaboration found in literature, i.e., scope, depth, duration and intensity, and clustered related quotes within each category into sub-themes. This provided a deeper understanding of the characteristics of the collaboration in the business agreement, which could then be used for analyzing its integration and application in sustainable management in infrastructure maintenance projects (see Figure 1). The NVivo software aided the analysis and iterative process of considering data related to each interview, emerging results, and theory in efforts to consolidate conclusions as they developed [59]. We also conducted follow-up sessions with some key respondents to increase the validity of the analysis and drawn conclusions [59].

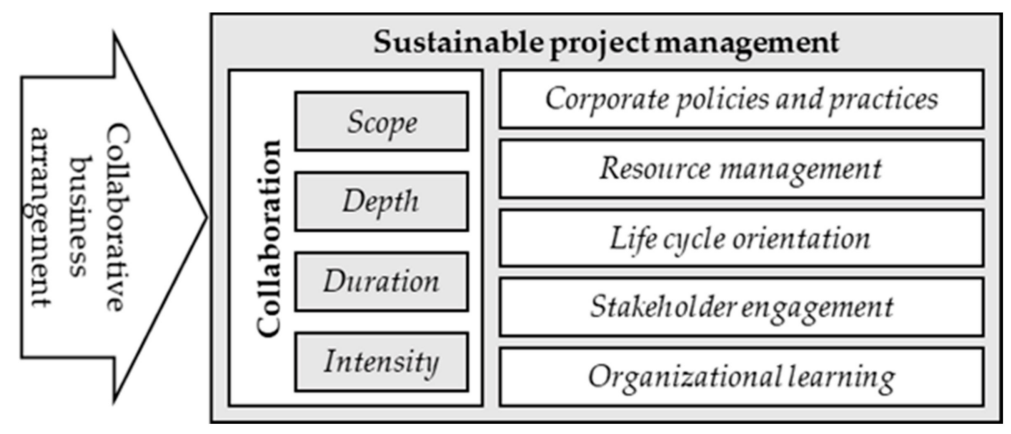

Figure 1. Schematic diagram of the analytical model.

\section{The Collaborative Business Arrangement}

The studied long-term collaborative business arrangement is based on a long-term contract for the supplier to maintain infrastructure within the municipality, which is in a mid-size city. The city has an arctic climate, which means that the season for outdoor work is restricted to approximately 6-7 months 
per year. The city is growing and needed to establish a broad contract, mainly for maintenance of roads but also for maintenance and minor construction of municipality-owned structures such as school yards, gardens and an airport. Although the municipality employs production personnel that perform many of these kinds of projects, increases in demand, due to growth of the city forced the municipality to either employ more personnel or establish a general contract covering much of this work. The municipality chose to establish a contract in 2014, involving a collaborative business arrangement. The division responsible for road infrastructure is also responsible for handling matters related to the contract for the municipality, but due to its general purpose, other departments and municipality-owned companies have been allowed to commission projects under it. On average, 100-200 projects have been conducted under the arrangement each year. These projects would otherwise have been undertaken by the production staff employed by the municipality or required individual contracts with separate procurement processes. The projects covered by the collaborative business arrangement vary in both size and content, from repair of minor road damage to renovation of playgrounds and larger asphalt projects (see Figure 2 for a schematic overview of the contract structure). Most of the maintenance and construction work conducted within the remit of the business arrangement mainly involves asphalt and/or earthwork.

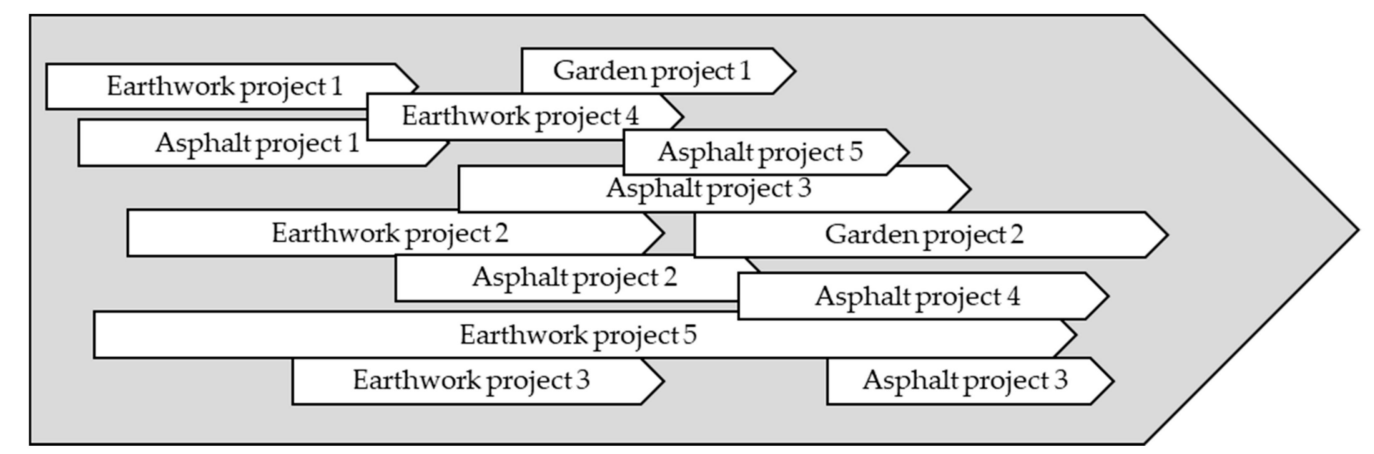

Figure 2. Schematic diagram of projects scheduled during a specific time of a working season during the municipality's 7 year general contract.

Some projects proceed during a whole season while others only require a couple of days work for a small team. This contract structure, with a lengthy collaborative business arrangement, facilitates a process where continuous improvements and organizational learning are natural parts of the everyday work. All projects conducted within the remit of the studied business arrangement are co-managed by people representing both the municipality and the supplier, which means that daily planning and communication are essential for their organization. The collaborative business arrangement with its inter-organizational nature has been crucial in many respects due to both the complexity of implementing projects in the municipality and the need to coordinate activities and schedules of numerous internal clients in different departments and companies within it. The following section describes how collaboration has been fostered, implemented and utilized in the collaborative business arrangement in terms of all four collaboration dimensions shown in Figure 1.

\subsection{Lengthy Collaboration Duration}

The duration of the focal business arrangement has been extended by several actions. Establishment of common ground in an early phase was facilitated by application of a competitive dialogue procedure during the procurement phase. This was started by asking interested suppliers to answer questions about how they could help to meet the municipality's various needs in a sustainable way, rather than setting a price. As the interviewed assistant procurer said, "One can talk about environmental benefits, you talk about longer activities and you talk about better planning. Based on that, we tried to figure out what kind of questions we had to ask [during the dialogues]./. .. What should we really negotiate about when we meet these suppliers and what are their requirements?" This procedure not only enabled assessment of the suppliers' 
competence and creativity, but also contributed to the openness that was mentioned by numerous interviewees as an important feature of the business arrangement.

Maintenance of infrastructure in cities traditionally involves extensive individual procurement processes for each project, which massively complicates suppliers' long-term planning of resource allocation. The length and structure of the studied business arrangement, involving multiple projects throughout each season, allows the municipality to provide the supplier with a list of projects planned for the coming season early in the year. Approximately 70 percent of all projects are pre-planned and part of this list. This greatly helps the supplier to plan assignment (and recruitment if necessary) of personnel and allocation of resources such as machinery and materials. The other projects (approximately 30 percent per year) are continuously commissioned throughout the seasons by different departments and municipally owned companies, in accordance with the municipality's emerging needs, then jointly planned and included in the project portfolio of the collaborative business arrangement.

During the initial year of the contract, the work was performed in a 'business as usual' manner, in parallel to the joint creation of a collaboration model that has been used during the rest of the business arrangement. This initial phase was enabled by the long contract duration (7 years), which provided the engaged stakeholders time to discuss and establish an appropriate project organization. The supplier's director highlighted the importance of the initial phase by stating that, "The whole first year was really a planning and start-up phase to get where we are now. With organization, with roles/positions, with attitudes and a declaration of collaboration." The joint creation of the collaboration model during the initial year helped the stakeholders to build trust, as noted by the client's project manager, "Trust and collaboration and everything like that takes time to build up. That [trust] actually reduces the need for control." Thus, the long duration has facilitated emergence of the collaboration, which has proved to be important for building trust and establishment of a single-organization mindset among the people engaged in the business arrangement.

\subsection{Strong Collaboration Intensity}

In the studied business arrangement, establishment of continuous, intense collaboration was an explicit aim and several measures have been taken to foster the desired inter-organizational cooperation. One was the straightforward act of basing the inter-organizational team in an office space in the municipality building. The joint office space is referred by several respondents as the heart of the collaboration, for example by a site manager at the supplier "... when you're attending a morning meeting here, it feels like it's a single organization, it's that simple." The joint office space is the site of all the planning and follow-ups of ongoing projects. Most of the joint planning is done during weekly meetings that all members of the inter-organizational project team generally attend. Beside these large weekly meetings, each of the two main units involved in the business arrangement (asphalt and earthwork) have separate weekly meetings to discuss their matters and projects more in detail. Interviewees representing both actors indicated that the project office promotes intense communication and effective decision-making. For example, the client's project manager stated that, "It's basically like working hand in hand", reflecting openness and trust between the actors. This was further highlighted by the supplier operational manager "... you just pick up the phone and call and ask the [municipality's] project manager, 'What applies in these circumstances?'”.

The strong collaboration and promotion of a single organization under the business arrangement have led to constructive dialogues between the supplier and internal clients within the municipality, expressed by the client's project manager as follows, "We work as one organization./... /In the past, the municipality handled all the communication with the [internal] client, but now the supplier can do so [call] before going there and doing any work." The importance of strong collaboration was also expressed by the operational manager as follows, "You can't sit at different sides of the table and not speak to each other, you have to have openness, open dialogue, open communication and when both actors understand this, nothing can go catastrophically wrong ... " The high intensity of the collaboration noted by the interviewees seems to promote open dialogue and trust. A clear example of the strong collaboration is the budget 
process, which is needed for larger projects conducted within the business arrangement. Each of the stakeholders generates a separate budget then they compare and discuss them and agree on the best overall solution for each project. This is part of the joint problem-solving process that continuously occurs between different people and stakeholders engaged in the business arrangement, as expressed by one of the site managers, " . . but we have to solve this together. How do we solve it in the best, cheapest and easiest way?" Another management practice that has promoted openness and trust according to several respondents is financial openness. The client has free access to the supplier's accounts regarding the business arrangement and can check them if necessary. This has been appreciated not only by the client, but also the supplier, since it has assisted the building of trust, as the supplier's site manger stated, "I think it's very good that it's controlled, because then you maintain the sharpness and the fact that you trust each other, no one does anything strange." This implies that the supplier has no motivation to cheat since it would destroy their credibility and eventually ruin the whole collaborative business arrangement.

The collaborative culture that emerged continuously during the first year was also facilitated by formulation of a declaration of collaboration during a workshop, which everyone engaged in the business arrangement had to sign at the end of the workshop. The declaration applies to everyone engaged in any way in the collaborative business arrangement, not only those that initially signed it. The declaration is not legally binding but expresses a list of cultural norms and attitudes that should be embedded in all work related to the arrangement. The supplier's regional manager expressed this as follows, "... it's not really a contract, but a moral document that we thoroughly discussed and agreed, this is how we should act in the contract [business arrangement]". This collaboration declaration is important during the daily operations, especially when the project organization needs to introduce new members. Overall, the declaration expresses factors, standards and behaviors that all actors are expected to promote or embrace, such as creative thinking, trust, good working environments, financial consensus and integrity, respect and ambition/foresight. All these integrative activities assist creation of the single-organization mentality that the interviewees unanimously agreed sets the rules for, and fosters development of, the collaborative business arrangement.

\subsection{Deep Collaboration}

Municipalities are generally organized in multiple hierarchical levels, from the city council down to the blue-collar workers. The studied collaborative business arrangement involves municipality workers from several of the levels due to the broad nature of the general contract and variety of projects it covers. Although the core project organization is rather small, many other municipality workers are engaged in specific projects since their departments are internal clients. Thus, from a municipality perspective the collaboration can be regarded as rather deep, as numerous internal actors representing multiple levels are engaged, although the intense collaboration within the project organization may only involve a couple of people. Similarly, the main supplier must deploy multiple internal competences to manage all the projects conducted within the business arrangement. Thus, although the core project organization is rather tight, the supplier often needs to involve several internal departments, especially in the larger projects within the business arrangement.

The pervasive engagement of each actor's organization in the business arrangement has contributed to the involvement of more peripheral people, and hierarchical levels, such as analysts and department managers. For example, the client's and supplier's economists collaborate to increase understandings of each other's processes and systems. The interviewed municipality department manager expressed this as follows, "You can't obstruct [each other] in a collaboration because then it doesn't work", meaning that everyone needs to be committed to the collaboration for it to become truly deep and provide optimal performance. This is also reflected in the understanding that if someone violates the collaboration declaration several times s/he can no longer be engaged in the work conducted within the business arrangement. Besides the declaration, there are clear descriptions of roles in the arrangement, including the purpose of the role, required competence, responsibilities and decision-making authority. The declaration and role descriptions help the project organization to select suitable people for specific 
roles, which is regarded as vital for the collaboration. Moreover, the responsible project manager at the client stressed that changes in personnel are subject to joint decisions, "All people who are joining the core project organization must be approved by both [stakeholders]".

The striking depth of the collaboration has been one of the reasons for the strong engagement of both actors. The single-organization mindset of the business arrangement is reflected in the common organization scheme, as the steering committee includes not only the representative with primary responsibility for the collaboration in each organization, but also the responsible procurer, client's division manager and supplier's business manager. The steering committee frequently attends the weekly project meetings in the joint office space, which shows the engagement at several hierarchical levels. This engagement has proved to be important for legitimation of the strong collaboration in the business arrangement and enhances understanding of how the business arrangement actually works for many people within the municipality.

\subsection{Suitable Collaboration Width}

Width often refers to the number of external stakeholders engaged in a collaboration, but this is not direct applicable in the context of the studied municipality maintenance contract. The main supplier often conducts most of the work with no assistance, while the municipality and main supplier jointly manage the multiple projects within the business arrangement. This significantly differs from the arrangement in typical construction (investment) projects, where multiple stakeholders are traditionally involved to provide specific technical competences and materials throughout the supply chain. In contrast, external support has been required in very few larger projects within the studied business arrangement. However, on these rare occasions, the project organization invites the external stakeholder to the weekly meetings where the ongoing project is planned and discussed. An alternative interpretation of this dimension that fits the context better is to treat the different departments and municipally owned companies as external clients. These (internal) clients order projects through the project organization (which manages the collaborative business arrangement) and finance the projects. In these cases, the project organization acts as a supplier that enters into a contractual relationship with the ordering unit. Seeing the different departments and municipality companies as external clients increases the importance of promotion and acceptance of the business arrangement within the municipality. The responsible division manager expressed that it has been important for acceptance that the administrative director has understood the importance and arrangement of the contract "we're lucky to have an administrative director who originated from the construction industry. He knows this/... /. He's been a great help in getting us to where we are." Acceptance and support from the municipality is very helpful to avoid risks for decision-making and other important processes becoming rather sluggish and bureaucratic.

\section{Collaboration as Part of Sustainable Project Management}

The aim of this paper, as already mentioned, is to increase the understanding of how to integrate and apply collaboration as part of sustainable management in infrastructure maintenance projects, based on a case study of a long-term infrastructure maintenance contract between a Swedish municipality and a major supplier. The case is an example of a highly demanding context in which the stakeholders must be actively engaged, and acceptance of these stakeholders is vital for successful implementation and sustainable deliverables. In this section, we discuss the illumination our empirical findings and previous literature provide regarding the establishment, maintenance and role of collaboration in sustainable project management. The discussion is based on the five previously mentioned dimensions of sustainable project management: corporate policies and practices, resource management, life cycle orientation, stakeholder engagement, and organizational learning [8].

The collaborative business arrangement has radically changed the way the municipality manages its maintenance work. This business arrangement can be considered a new organizational strategy [23], or corporate practice [8], that has changed the temporal focus from short-term individual projects to 
more long-term processes, or even product life cycle, thereby enabling continuous improvement and organizational learning. This has been crucial, as the short-term objectives traditionally applied in construction projects (often specified in time, cost and quality terms) have been shown to hamper progress towards more long-term objectives [1]. Thus, a shift in focus may be essential to incorporate sustainability principles into new organizational business strategies. Further, the duration of the collaboration may be crucial for incorporating sustainable project management practices, as a long-term mindset is required, which often emerges gradually over time [49]. One of the key findings of this study is that organizational acceptance of a new business strategy is crucial. The long duration and multi-project structure of the studied business arrangement has influenced practices of all the stakeholders engaged in the implementation of various maintenance works. Moreover, the engagement of several departments (collaboration width) and hierarchical levels (collaboration depth) within the client organization have been key factors for the successful implementation of the collaborative arrangement, which has supported sustainable project management. The importance of corporate-level engagement in the implementation of new practices has been previously emphasized by sustainable project management scholars [8]. However, this study shows that a wider scope might be equally important (together with high degrees of collaboration in terms of depth, width and duration) for incorporating more sustainable management principles into a client organization such as a municipality with multiple departments-all of which must, to some degree, embrace and accept new management practices.

The intense collaboration in the studied business arrangement has proved to have positive effects on resource management, which is sometimes regarded as the main objective of sustainable project management [25]. In construction this has often been interpreted as reducing the substantial use of resources, which has negative environmental effects [38]. However, in sustainable project management, not only resources that impact the environment, but also the economic and social capital of involved organizations and other stakeholders should be considered [28]. In the studied case, continuous joint planning facilitated by the intense collaboration, together with the multi-project arrangement, has had significant effects on resource management in terms of all three forms of capital. From a social capital perspective, it has particularly enhanced conditions for the supplier's employees by prolonging the season, increasing security of employment, and enabling better resource (human and material) allocation. Consequently, the supplier has been able to retain key competences more successfully, thereby facilitating increases in productivity over time. These aspects have recognized importance in the sustainable project management paradigm, e.g., [28]. In addition, new improved machinery could be introduced due to the large scale of the arrangement, which has improved the working environment and thus the social capital. Moreover, the improvements in project scheduling and resource allocation throughout entire seasons has enabled more re-cycling of materials, thus contributing to more economically and ecologically effective use of resources. Thus, the intense collaboration has significantly contributed to all aspects of sustainable resource management.

Life cycle approaches described in the literature often tend to be limited to specific projects, and thus focus on short-term evaluations rather than a life cycle orientation [8]. However, we found that introduction of a collaborative arrangement with a long duration promoted a shift in attention from short-term solutions towards a life cycle perspective. This supports previous claims that integrating the sustainability concept into project management may stretch the 'system boundaries' of project management in this manner [29]. The long duration, together with the selection of the supplier based upon competence and creativity, promoted incorporation of sustainability into the mindset of participants in the collaborative business arrangement from the outset. Basing procurement and supplier selection upon competences, rather than lowest price, also has previously recognized importance for both innovation and sustainable project management [33].

Considering and respecting potential interests of stakeholders is essential in the management of any project, but especially large projects, such as infrastructure projects, that are often complex and inter-organizational $[8,15]$. As sustainability becomes more important for project success, the numbers 
of stakeholders that must be coordinated and engaged in project processes are increasing [1]. Moreover, open, flexible, joint processes among stakeholders are required in sustainable project management, and hence, deep and wide collaboration is becoming increasingly essential [8]. The high degree of collaboration from the outset of the studied business arrangement has clearly helped the integration of a sustainability orientation into the project management. Engaging numerous departments and several hierarchical levels of the public client's organization has contributed to an understanding and acceptance of somewhat higher initial costs for sustainable solutions, which might decrease total life cycle costs and environmental impacts. The open dialogue between engaged stakeholders in the implementation of projects has contributed to a creative climate where all opinions are welcome and joint decisions are taken based upon the best overall (and hence sustainable) solutions to meet current needs. Thus, a key finding is that a high degree of stakeholder engagement may provide an important connection between traditional project management and a more sustainable form that also considers social and ethical aspects [38].

Organizational learning is regarded as a highly desirable process that is difficult to foster in the construction industry due to the focus on short-term objectives in individual projects. In contrast, the multiple project set-up in the studied collaborative business arrangement shifted the focus to recurrent project processes. All projects performed within the remit of the arrangement are managed by the same organization, with members representing both the client and supplier, which increases chances for organizational learning and continuous improvements based upon past projects. The high degree of collaboration, particularly in terms of intensity and depth, also assist organizational learning since the deliveries in individual projects are discussed by people engaged in the business arrangement with diverse roles, at multiple levels, in both the client and supplier organizations. Hence, the arrangement facilitate improvements in products, processes and minimizes waste, which is a key aspect of sustainability [8], through discussions about past projects.

\section{Conclusions}

This paper contributes to the ongoing discussion on sustainable project management, particularly in complex infrastructure maintenance work that has long-lasting environmental and social effects. Our analysis of an arrangement for maintaining public infrastructure in a Swedish municipality extends the applied five-dimensional conceptual framework [8], by showing that a high degree of collaboration may play a vital role in all dimensions of sustainable project management. Moreover, all collaboration dimensions (duration, intensity, depth, width) affect diverse aspects of sustainable project management, meaning that collaboration should be integrated into any management practices intended to promote sustainability. This is consistent with previous conclusions that proactive stakeholder participation is crucial for any sustainable project management approach [1]. The findings also confirm that effectiveness and innovation are facilitated by collaboration [12,14], and show that it promotes sustainable deliveries based upon organizational learning and continuous improvements. Hence, the findings also contribute to the construction management literature on partnering concepts that have emerged in recent decades and are regarded as essential for construction improvements. The collaborative business arrangement that invites various stakeholders (both internal and external) to engage was found to support sustainability. This corroborates the positive relation between collaboration and sustainability identified in a previous investigation of alliance contracts in a public infrastructure context [9]. Thus, this study offers an encouraging example of how extensive collaboration can be fostered and play an important role in sustainable project management practices.

In summary, a high degree of collaboration in all four dimensions is important for sustainable project management, and three findings warrant particular attention when integrating collaboration in sustainable project management and areas for further research. First, the duration of the collaboration strongly influences the capacity for organizational learning, an important aspect of SPM, since it facilitates a shift in focus, from projects towards processes, that promotes continuous improvements. The findings show that the life cycle orientation in this arrangement fixes attention 
on the products (e.g., roads or schools) life cycle rather than projects, leading to better solutions from a sustainability perspective. Second, they show that the intensity of the collaboration is important for a single-organization mindset and the joint problem-solving and planning. The findings reveal that joint planning and continuous project meetings facilitate effective use of resources, another key aspect in achieving sustainability. Third, both deep and wide collaboration is important for stakeholder engagement. Joint decisions based on various kinds of knowledge and a single-organizational mindset have been enabled by the high degree of collaboration and engaging multiple hierarchical levels has been important for the implementation of the new practices and organizational strategy. Corporate-level engagement is essential, but involvement of lower levels that are operationally involved in the implementation of practices and strategies is also crucial for the implementation of any sustainable project management practices.

Although the single case study provides relevant findings based on in-depth data about the integration and application of collaboration in SPM, the study has its limitations. Foremost, the single case-based findings cannot be directly extended to inter-organizational infrastructure projects generally. Their relevance to other inter-organizational project contexts requires examination in future research involving other contexts and regions. An especially interesting context may be publicly procured investment projects where new products, with a long life span of over 100 years, are constructed. It could also be interesting and relevant to apply a multiple case study approach and/or widen the scope by studying how maintenance projects affect more peripheral stakeholders from society. Nevertheless, the findings provide new insights into ways that collaborative business arrangements can support sustainable deliveries and management practices in inter-organizational projects, which may have wider relevance, particularly as interest in collaboration in construction supply-chains has increased during the past decade $[12,14]$.

In terms of managerial implications, this study clearly indicates that the choices of procurement strategy and contract model in public maintenance work affect the degree to which sustainability is likely to be considered. Using collaborative business arrangements, public clients can promote engagement of various stakeholders in intense, long-term joint planning and development activities that encourage the formulation and implementation of more sustainable solutions. Engaging stakeholders in collaborative activities also increases their understanding of multiple issues and perspectives, thereby promoting their required acceptance of chosen solutions.

Author Contributions: The knowledge and experience of each author has equally contributed to the study and final version of the article. J.L. and L.L. had equal responsibility for conceiving and designing the case study, collecting and analyzing the data, and writing the paper. All authors have read and agreed to the published version of the manuscript.

Funding: The authors would like to acknowledge the funding from the strategic innovation program InfraSweden2030 supported by VINNOVA.

Conflicts of Interest: The authors declare no conflict of interest. The funders had no role in the design of the study; in the collection, analyses, or interpretation of data; in the writing of the manuscript, or in the decision to publish the results.

\section{References}

1. Silvius, A.J.; Schipper, R.P. Sustainability in project management: A literature review and impact analysis. Soc. Bus. 2014, 4, 63-96. [CrossRef]

2. Winch, G.M. Zephyrs of creative destruction: Understanding the management of innovation in construction. Build. Res. Inf. 1998, 26, 268-279. [CrossRef]

3. Bygballe, L.E.; Swärd, A.R.; Vaagaasar, A.L. Coordinating in construction projects and the emergence of synchronized readiness. Int. J. Proj. Manag. 2016, 34, 1479-1492. [CrossRef]

4. Bresnen, M.; Marshall, N. Partnering in construction: A critical review of issues, problems and dilemmas. Constr. Manag. Econ. 2000, 18, 229-237. [CrossRef]

5. Karrbom Gustavsson, T.; Hallin, A. Rethinking dichotomization: A critical perspective on the use of "hard" and "soft" in project management. Int. J. Proj. Manag. 2014, 32, 568-577. [CrossRef] 
6. Ika, L.A. Project success as a topic in project management journals. Proj. Manag. J. 2009, 40, 6-19. [CrossRef]

7. Larsson, J.; Eriksson, P.E.; Pesämaa, O. The importance of hard project management and team motivation for construction project performance. Int. J. Manag. Proj. Bus. 2018, 11, 275-288. [CrossRef]

8. Armenia, S.; Dangelico, R.M.; Nonino, F.; Pompei, A. Sustainable project management: A conceptualizationoriented review and a framework proposal for future studies. Sustainability 2019, 11, 2664. [CrossRef]

9. Kivilä, J.; Martinsuo, M.; Vuorinen, L. Sustainable project management through project control in infrastructure projects. Int. J. Proj. Manag. 2017, 35, 1167-1183. [CrossRef]

10. Yu, M.; Zhu, F.; Yang, X.; Wang, L.; Sun, X. Integrating Sustainability into construction Engineering Projects: Perspective of Sustainable Project Planning. Sustainability 2018, 10, 784. [CrossRef]

11. Eskerod, P.; Huemann, M. Sustainable development and project stakeholder management: What standards say. Int. J. Manag. Proj. Bus. 2013, 6, 36-50. [CrossRef]

12. Bygballe, L.E.; Jahre, M.; Swärd, A. Partnering relationships in construction: A literature review. J. Purch. Supply Manag. 2010, 16, 239-253. [CrossRef]

13. Eriksson, P.E.; Volker, L.; Kadefors, A.; Lingegård, S.; Larsson, J.; Rosander, L. Collaborative procurement strategies for infrastructure projects: A multiple-case study. Proc. Inst. Civ. Engin. Manag. Procure. Law 2019, 172, 197-205. [CrossRef]

14. Eriksson, P.E. Partnering in engineering projects: Four dimensions of supply chain integration. J. Purch. Supply Manag. 2015, 21, 38-50. [CrossRef]

15. Eriksson, P.E.; Larsson, J.; Pesämaa, O. Managing complex projects in the infrastructure sector-A structural equation model for flexibility-focused project management. Int. J. Proj. Manag. 2017, 35, 1512-1523. [CrossRef]

16. Jackson, M.; Stewart, R.A.; Fielding, K.S.; Cochrane, J.; Beal, C.D. Collaborating for Sustainable Water and Energy Management: Assessment and Categorisation of Indigenous Involvement in Remote Australian Communities. Sustainability 2019, 11, 427. [CrossRef]

17. Jobidon, G.; Lemieux, P.; Beauregard, R. Implementation of Integrated Project Delivery in Quebec's Procurement for Public Infrastructure: A Comparative and Relational Perspective. Sustainability 2018, 10, 2648. [CrossRef]

18. Schoenmaker, R.; de Bruijn, H. Embracing complexity in performance-based contracts for road maintenance. Int. J. Product. Perform. Manag. 2016, 65, 4-24. [CrossRef]

19. Eriksson, P.E. Procurement strategies for enhancing exploration and exploitation in construction projects. J. Financ. Manag. Prop. Constr. 2017, 22, 211-230. [CrossRef]

20. Brundtland, G.H. What is sustainable development. In Our Common Future; La Trobe University: Melbourne, Australia, 1987; pp. 8-9.

21. Elkington, J. Cannibals with Forks: The Triple Bottom Line of 21st Century Business; Capstone Publishing Ltd.: Oxford, UK, 1997.

22. Gareis, R.; Huemann, M.; Martinuzzi, A. What can project management learn from considering sustainability principles. Proj. Perspect. 2011, 33, 60-65.

23. Baumgartner, R.J.; Ebner, D. Corporate sustainability strategies: Sustainability profiles and maturity levels. Sustain. Dev. 2010, 18, 76-89. [CrossRef]

24. Silvius, A.G.; De Graaf, M. Exploring the project manager's intention to address sustainability in the project board. J. Clean. Prod. 2019, 208, 1226-1240. [CrossRef]

25. Deland, D. Sustainability through project management and net impact. In PMI Global Congress North America; Project Management Institute: Orlando, FL, USA, 2009.

26. Silvius, A.G. Sustainability as a new school of thought in project management. J. Clean. Prod. 2017, 166, 1479-1493. [CrossRef]

27. Martens, M.L.; Carvalho, M.M. The challenge of introducing sustainability into project management function: Multiple-case studies. J. Clean. Prod. 2016, 117, 29-40. [CrossRef]

28. Tharp, J. Project management and global sustainability. In PMI Global Congress—EMEA; Project Management Institute: Marseilles, France, 2012.

29. Jugdev, K.; Müller, R. A retrospective look at our evolving understanding of project success. Proj. Manag. J. 2005, 36, 19-31. [CrossRef]

30. Pade, C.; Mallinson, B.; Sewry, D. An Elaboration of Critical Success Factors for Rural ICT Project Sustainability in Developing Countries: Exploring the Dwesa Case. J. Inf. Technol. Case Appl. 2008, 10, 32-55. [CrossRef] 
31. Craddock, W.T. How Business Excellence Models Contribute to Project Sustainability and Project Success. In Sustainability Integration for Effective Project Management; Silvius, G., Tharp, J., Eds.; IGI Global Publishing: Hershey, PA, USA, 2013. [CrossRef]

32. Silvius, A.J.G.; Schipper, R. Sustainability in the Business Case. In Proceedings of the 26th IPMA World Congr., Crete, Greece, 29-31 October 2012; pp. 1062-1069.

33. Taylor, T. Sustainability Interventions-for Managers of Projects and Programmes; The Higher Education Academy, Centre for Education in the Built Environment: Salford, UK, 2010.

34. Garvare, R.; Isaksson, R. Sustainable development: Extending the scope of business excellence models. Meas. Bus. Excell. 2001, 5, 11-15. [CrossRef]

35. Robichaud, L.B.; Anantatmula, V.S. Greening project management practices for sustainable construction. J. Manag. Eng. 2011, 27, 48-57. [CrossRef]

36. Freeman, R.E. Strategic Management: A Stakeholder Approach; Cambridge University Press: Cambridge, UK, 2010.

37. Martens, M.L.; Carvalho, M.M. Key factors of sustainability in project management context: A survey exploring the project managers' perspective. Int. J. Proj. Manag. 2017, 35, 1084-1102. [CrossRef]

38. Marcelino-Sádaba, S.; González-Jaen, L.F.; Pérez-Ezcurdia, A. Using project management as a way to sustainability. From a comprehensive review to a framework definition. J. Clean. Prod. 2015, 99, 1-16. [CrossRef]

39. Silvius, A.G.; Schipper, R.; Nedeski, S. Sustainability in project management: Reality bites. PM World J. 2012, $2,1-14$.

40. Shenhar, A.J.; Dvir, D.; Levy, O.; Maltz, A.C. Project success: A multidimensional strategic concept. Long Range Plan. 2001, 34, 699-725. [CrossRef]

41. Gann, D.M.; Salter, A.J. Innovation in project-based, service-enhanced firms: The construction of complex products and systems. Res. Policy 2000, 29, 955-972. [CrossRef]

42. Larsson, L.; Larsson, J. Sustainable Development in Project-Based Industries-Supporting the Realization of Explorative Innovation. Sustainability 2018, 10, 683. [CrossRef]

43. Cantarelli, C.; van Wee, B.; Molina, E.J.E.; Flyvbjerg, B. Different cost performance: Different determinants? The case of cost overruns in Dutch transport infrastructure projects. Transp. Policy 2012, 22, 88-95. [CrossRef]

44. Han, S.H.; Yun, S.; Kim, H.; Kwak, Y.H.; Park, H.K.; Lee, S.H. Analyzing schedule delay of mega project: Lessons learned from Korea Train Express. IEEE Trans. Eng. Manag. 2009, 56, 243-256. [CrossRef]

45. Pero, M.; Moretto, A.; Bottani, E.; Bigliardi, B. Environmental collaboration for sustainability in the construction industry: An exploratory study in Italy. Sustainability 2017, 9, 125. [CrossRef]

46. Shin, N.; Park, S.H.; Park, S. Partnership-Based Supply Chain Collaboration: Impact on Commitment, Innovation, and Firm Performance. Sustainability 2019, 11, 449. [CrossRef]

47. Nyström, J. The definition of partnering as a Wittgenstein family-resemblance concept. Constr. Manag. Econ. 2005, 23, 473-481. [CrossRef]

48. Kadefors, A. Trust in project relationships-inside the black box. Int. J. Proj. Manag. 2004, 22, $175-182$. [CrossRef]

49. Bresnen, M.; Marshall, N. The engineering or evolution of co-operation? A tale of two partnering projects. Int. J. Proj. Manag. 2002, 20, 497-505. [CrossRef]

50. Fawcett, S.E.; Magnan, G.M. The rhetoric and reality of supply chain integration. Int. J. Phys. Distrib. Logist. Manag. 2002, 32, 339-361. [CrossRef]

51. Leuschner, R.; Rogers, D.S.; Charvet, F.F. A meta-analysis of supply chain integration and firm performance. J. Supply Chain Manag. 2013, 49, 34-57. [CrossRef]

52. Xue, X.; Shen, Q.; Ren, Z. Critical review of collaborative working in construction projects: Business environment and human behaviors. J. Manag. Eng. 2010, 26, 196-208. [CrossRef]

53. Van der Vaart, T.; van Donk, D.P. A critical review of survey-based research in supply chain integration. Int. J. Prod. Econ. 2008, 111, 42-55. [CrossRef]

54. Flynn, B.; Huo, B.; Zhao, X. The Impact of Supply Chain Integration on Performance: A Contingency and Configuration Approach. J. Ops. Manag. 2010, 28, 58-71. [CrossRef]

55. Bayliss, R.; Cheung, S.; Suen, H.; Wong, S.-P. Effective partnering tools in construction: A case study on MTRC TKE contract in Hong Kong. Int. J. Proj. Manag. 2004, 22, 253-263. [CrossRef] 
56. Gil, N. Developing Cooperative Project Client-Supplier Relationships: How Much to Expect from Relational Contracts? Calif. Manag. Rev. 2009, 51, 144-169. [CrossRef]

57. Martinsuo, M.; Ahola, T. Supplier Integration in Complex Delivery Projects: Comparison between Different Buyer-Supplier Relationships. Int. J. Proj. Manag. 2010, 28, 107-116. [CrossRef]

58. Kadefors, A.; Björlingson, E.; Karlsson, A. Procuring service innovations: Contractor selection for partnering projects. Int. J. Proj. Manag. 2007, 25, 375-385. [CrossRef]

59. Yin, R.K. Case Study Research: Design and Methods; Sage Publications: Thousand Oaks, CA, USA, 2013.

60. Krantz, J.; Feng, K.; Larsson, J.; Olofsson, T. Eco-Hauling'principles to reduce carbon emissions and the costs of earthmoving-A case study. J. Clean. Prod. 2019, 208, 479-489. [CrossRef]

61. Knott, J.F.; Jacobs, J.M.; Sias, J.E.; Kirshen, P.; Dave, E.V. A Framework for Introducing Climate-Change Adaptation in Pavement Management. Sustainability 2019, 11, 4382. [CrossRef]

62. Patton, M.Q. Qualitative Research E Evaluation Methods; SAGE Publications: Thousand Oaks, CA, USA, 2015.

63. Miles, M.B.; Huberman, A.M. Qualitative Data Analysis: An. Expanded Sourcebook; Sage Publications: Thousand Oaks, CA, USA, 1994.

64. Zamawe, F.C. The implication of using NVivo software in qualitative data analysis: Evidence-based reflections. Malawi Med. J. 2015, 27, 13-15. [CrossRef] [PubMed]

(C) 2020 by the authors. Licensee MDPI, Basel, Switzerland. This article is an open access article distributed under the terms and conditions of the Creative Commons Attribution (CC BY) license (http://creativecommons.org/licenses/by/4.0/). 